\title{
escravidão, imigração e suas funções em uma economia exportadora - juiz de fora, segunda metade do XIX: O caso da companhia união \& indústria*
}

\author{
Fernando Gaudereto Lamas \\ Doutorando em História Econômica e Social pela Universidade Federal Fluminense (UFF), professor \\ do Colégio de Aplicação João XXIII da Universidade Federal de Juiz de Fora (UFJF). \\ Luís Eduardo de Oliveira \\ Doutor em História Social pela Universidade Federal Fluminense (UFF) e professor do Centro \\ Federal de Educação Tecnológica de Minas Gerais (CEFET-MG), campus Leopoldina.
}

\section{RESUMO}

O objetivo deste artigo é discutir a utilização da mão de obra escrava e livre imigrante na construção da Rodovia União \& Indústria. Nossa pesquisa mostrou que, a partir do final do ano de 1854 e ao longo do ano de 1855, Mariano Procópio iniciou a prática ilegal de alugar escravos para a obra em questão. Prática comum especialmente quando se tratava de empresas privadas, o aluguel de escravos era considerado ilegal quando voltado para a construção de obras públicas. Outro mito que foi questionado por nossa pesquisa refere-se à não especialização da mão de obra escrava, pois encontramos a prática de aluguel de escravos especializados em muitas funções. Portanto, a mão de obra escrava somou-se à já conhecida mão de obra livre imigrante, especialmente de origem alemã, na construção da dita rodovia.

Palavras-chave: Escravidão. Zona da Mata Mineira. Século XIX. Mão de obra livre imigrante. Rodovia União \& Indústria.

\begin{abstract}
This article discusses the utilization of slave labour on the construction of the road União \& Indústria. Our research showed that, from the end of 1854 through the year of 1855 , Mariano Procópio started the illegal practice of renting slaves to work on the above mentioned road. In spite of what the numbers displayed, the local historiography accepted the myth of free immigrant work. The rental of slaves, an especially common practice among private companies, was considered illegal in the construction of public works. Another myth that was questioned by our research concerns the non-specialization of slave labour, since we have found the practice of renting specialized slaves to perform many functions. Therefore, the slave workers joined the already known immigrant workers, especially the ones of German origin, in the making of the above mentioned road.
\end{abstract}

Key-words: Slavery. Zona da Mata Mineira. Nineteenth century. Immigrant work. Road União \& Indústria.

* Submetido: outubro, 2011; aceito: dezembro, 2011. 


\section{A rodovia União \& Indústria e seu impacto sobre a economia regional}

A Rodovia União \& Indústria, que liga Juiz de Fora à Petrópolis ${ }^{1}$, foi construída entre 1855 e 1861 pela Companhia União \& Indústria (CUI), criada em 1853 pelo cafeicultor Mariano Procópio Ferreira Lage, detentor de uma concessão imperial para manter e explorar a estrada durante meio século - o que não ocorreu de fato, pois por volta de 1879 a CUI entrou em processo de falência, levando a um relativo abandono daquela primeira via e seus diversos ramais (STEHLING, 1979: 121-145).

Além dos 144 quilômetros macadamizados e carroçáveis da Rodovia União \& Indústria, a Companhia União \& Indústria construiu também, até 1868, outros quatro ramais (Posse-Aparecida, Serraria-Mar de Espanha, Paraibuna-Flores e Juiz de Fora-Ubá), com 264 quilômetros de caminhos vicinais interligando aquela estrada-tronco às mais importantes áreas cafeeiras do Vale do Paraíba Fluminense e da Zona da Mata mineira (STEHLING, 1979: 143).

A constituição de um sistema viário tecnologicamente avançado para a época e que possibilitou uma interligação eficaz entre Juiz de Fora e o Rio de Janeiro, inicialmente através da Rodovia União \& Indústria, inaugurada em 1861, constitui um marco fundamental para o incremento e a diversificação da população e das atividades urbanas daquele município nas décadas 1860 e 1870.

A Rodovia União \& Indústria foi considerada por muitos historiadores como uma das obras mais importantes, em termos rodoviários, realizadas na segunda metade do século XIX. Waldemar de Almeida Barbosa classificou em sua obra História de Minas que "a genuína pioneira das modernas rodovias foi a União \& Indústria” (BARBOSA, 1979: 479). Essa obra deve ainda ser encarada como parte do esforço realizado no Brasil para se adequar aos novos padrões impostos pala Segunda Revolução Industrial, que primavam pela modernização dos meios de transportes visando à agregação de valor aos produtos primários (GITAHI, 1996: 49-50; SEVCENKO, 1998: 7-48).

1 Desse ponto para os portos do Rio de Janeiro a viagem continuava pela antiga estrada da serra da Estrela e, em seguida, pelos 14,5 Km de trilhos da E. F. Mauá. 
Tal empreendimento abriu novos horizontes à cafeicultura da Zona da Mata, permitindo o escoamento regular e em larga escala de uma produção que continuou expandindo-se vigorosamente até 1926, beneficiada não apenas pela facilitação do transporte, mas também pela disponibilidade de terras e de mão de obra, mesmo após a Abolição, e pela organização de um sistema creditício e financeiro vinculado aos interesses dos cafeicultores da região (PIRES, 1993; SARAIVA, 2005: 185-189).

A construção da Rodovia União \& Indústria, com seus vários ramais, a chegada dos trilhos da Estrada de Ferro Dom Pedro II e o estabelecimento de uma malha ferroviária na Zona da Mata mineira, capitaneada pela Estrada de Ferro Leopoldina, por outro lado, contribuíram também para que Juiz de Fora se configurasse, nos últimos três decênios do século XIX, como um dos mais importantes entrepostos comerciais do estado $^{2}$. Isso porque, durante quase todo esse período, parte significativa dos produtos exportados e importados por diversas regiões de Minas Gerais (Centro, Oeste, parte do Sul e da Zona da Mata) e de Goiás tinha que passar pela cidade, permitindo que nela se desenvolvesse um vigoroso comércio varejista e atacadista e, ao mesmo tempo, inúmeras atividades manufatureiras. Como consequência, desde meados da década de 1860 , tal centro urbano passou a aglutinar grandes interesses, tornandose, a partir de então, palco de vultosos negócios, de intensa circulação de mercadorias e acumulação de capitais (PAULA, 1976: 60-62; PIRES, 1993: 110-113; GIROLETTI, 1987: 28-35, 46-47).

2 Em 1875, Juiz de Fora passou a ser servida também pela "Linha do Centro" da Estrada de Ferro D. Pedro II, que, partindo de Barra do Piraí, "descia" o Vale do Paraíba Fluminense até Entre-Rios (hoje Três Rios), de onde "subia" em direção a Minas, em trajeto mais ou menos paralelo ao da Rodovia União e Indústria. Quanto à malha ferroviária da Mata mineira, Peter Blasenhein esclarece que a E. F. Leopoldina, que em 1877 restringia-se a operar o trecho Porto Novo do Cunha-Cataguases, cresceu rapidamente incorporando outras pequenas companhias, fundadas nas décadas de 1870 e 1880, como as estradas de ferro Pirapetinga, Alto Muriaé, União Mineira, Juiz de Fora-Piau e uma série de linhas igualmente falidas na província do Rio. Em 1898, aquela empresa foi reorganizada e passou para o controle de capitalistas ingleses, com a denominação Leopoldina Railway (BLASENHEIN, 1996: 81-110; MELO, 2002: 173-195). 


\section{O papel da mão de obra escrava na construção da União \& Indústria}

De acordo com o historiador Wilson de Lima Bastos, autor de uma obra de cunho laudatório sobre Mariano Procópio, a construção da rodovia iniciou-se em 1856 (BASTOS, 1991:24) e só tomou impulso no ano de 1858 com a chegada dos imigrantes alemães. Logo, essas datas corroboravam a errônea ideia de que teriam sido esses imigrantes germânicos os únicos responsáveis pela construção da afamada União \& Indústria, já que, em seu estudo, Bastos não mencionou a utilização de escravos no período 1856-1858.

Carlos Oberacker Júnior chegou a afirmar que houve participação de escravos na construção da rodovia, ao menos no tocante aos serviços mais brutos, sem, contudo precisar a quantidade (OBERACKER JÚNIOR, 1985: 297). Porém, o mito de que a história de Juiz de Fora se fez exclusivamente através da contribuição de imigrantes (alemães, italianos, portugueses, sírios, libaneses, etc.) permaneceu atual através das comemorações de efemérides locais, como a festa dos 150 anos da cidade. Nessa festa, foi lançado por um jornal local um pequeno caderno onde se contou a história dos imigrantes e se excluiu a fundamental participação da mão de obra escrava (TRIBUNA DE MINAS, 2000) ${ }^{3}$.

Como atestam os relatos coevos e os dados reunidos por diferentes pesquisadores, em seus empreendimentos rodoviários a Companhia União \& Indústria (CUI) não utilizou apenas mão de obra livre, como obrigava o contrato que firmou com o governo imperial, e como sugerem ainda hoje certos estudiosos da história local. A esse respeito, apesar de enfatizarem no seu livro Viagem ao Brasil (1865-1866) que normas contratuais proibiam expressamente o emprego de escravos na construção da rodovia que ligava Juiz de Fora a Petrópolis, o naturalista Louis Agassiz e sua esposa, Elizabeth Cary Agassiz, indicaram também que, na prática, tal regra foi ignorada, pois constataram que "nos trabalhos de certo gênero não se achou meio de substituir essa pobre gente".4.

3 Imigrantes: 150 anos Juiz de Fora. In: Tribuna de Minas. Juiz de Fora: Esdeva, 2000. Para uma crítica desta visão cf. Saraiva (2001: 19-21).

4 Francisco Foot e Hardman eVictor Leonardi, contudo, equivocaram-se ao concluírem, a partir dessas observações dos Agassiz, que na construção da estrada União e Indústria somente foram empregados operários livres, germânicos e portugueses. 
Na verdade, como enfatizam Luiz José Stheling, Domingos Giroletti e Sérgio de Oliveira Birchal, entre 70\% e 80\% da força de trabalho dos serviços de abertura da principal rodovia construída pela Companhia União \& Indústria compunham-se de cativos, num total de cerca de dois mil escravos, em geral, alugados de seus acionistas ou das companhias inglesas de mineração de Cocais e de Congo Soco e de fazendeiros das regiões cortadas por aquela via ${ }^{5}$. Em 1855, em especial, ano em que se iniciaram os trabalhos de abertura da Rodovia União \& Indústria, de acordo com Sérgio de Oliveira Birchal, a CUI empregou entre 515 e 818 escravos (BIRCHAL, 1998: 10). Possivelmente, parte significativa desses cativos atuou na construção dos trechos daquela estrada que não apenas cortaram como também redefiniram importantes áreas do núcleo central e dos arrabaldes de Juiz de Fora. A partir de informações que encontrou nos relatórios das assembleias gerais de acionistas da Companhia União \& Indústria, realizadas entre 1856 e 1866, Sérgio de Oliveira Birchal produziu uma descrição ainda mais abrangente do conjunto da força de trabalho, cativa e livre, que essa empresa recrutou no período de maior intensidade de suas atividades. Naquele primeiro ano, como informa o autor:

A companhia (União \& Indústria) empregava 1.102 pessoas; entre elas, 900 escravos que constituíam quase $82 \%$ da força de trabalho total. Dos 900 escravos, 48 eram empregados na produção de carvão; 96 eram empregados como pedreiros, cozinheiros etc., e como seus assistentes e aprendizes, nas várias oficinas e seções da estrada; os 756 restantes trabalhavam na constru-

Na verdade, o relato desses viajantes refere-se à utilização exclusiva de não-escravos apenas em 1865, nos serviços de conservação dessa rodovia (ver HARDMAN e LEONARDI, 1991: 91-92; AGASSIZ e AGASSIZ, 2000: 80-83).

5 Com base nos relatórios das assembleias gerais de acionistas da Companhia União e Indústria dos anos de 1856 e 1857, Sérgio de Oliveira Birchal concluiu que os escravos empregados pela empresa provinham de outras companhias, de fazendeiros da região e de alguns dos principais acionistas da CUI: "Em 7 de junho de 1855, por exemplo, a CUI assinou um contrato com a Companhia de Cocais para alugar 305 escravos. (...) No relatório de 1857, o presidente agradeceu dois acionistas pelos serviços prestados à companhia: José Antonio da Silva Pinto (o barão de Bertioga) e Lino José Ferreira Armond. Entre outras coisas, (Silva) Pinto alugou à companhia mais de 100 escravos de seu próprio plantel que estavam trabalhando na construção da rodovia entre Matias (Barbosa) e a ponte sobre o rio Paraibuna" (STEHLING, 1979: 144-145; GIROLETTI, 1987: 63-65 \& BIRCHAL, 1998: 10-11). 
ção e manutenção da rodovia. (...) Em 1857, havia 804 escravos trabalhando para a companhia, mas não há informação acerca do total de trabalhadores empregados. (...) Em 1858, a companhia empregava 2.636 trabalhadores: 1.136 eram empregados na seção da rodovia entre Juiz de Fora e Paraíba (do Sul). Deste número, 800 eram escravos; isto é, 70\%. (...) Os outros 1.500 eram empregados na seção entre Petrópolis e Paraíba do Sul, mas não há informação acerca do status destes trabalhadores (...), porém, é razoável supor que a mão de obra escrava representava uma grande parcela (BIRCHAL, 1998: 08-12) ${ }^{6}$.

É possível inferir que, mesmo na operação das grandes oficinas que instalou nas imediações da Estação Rio Novo, primeiro complexo manufator a ser estruturado naquele município mineiro ${ }^{7}$, a CUI não prescindiu do braço servil, como demonstra também uma outra evidência concreta sobre o uso de trabalhadores escravizados, neste caso em associação com artífices e operários livres, nas atividades manufatureiras desenvolvidas localmente na década de 1860. A evidência em questão refere-se à compra de uma carta de alforria, paga "por terceiros", em benefício do escravo Jorge Carneiro dos Santos, passada no Cartório do $1^{\circ}$ Ofício de Notas da cidade em 18 de janeiro de 1869. Segundo Antônio Henrique Lacerda:

Este cativo, marceneiro, tornou-se devedor da quantia de 1:500\$000 (um conto e quinhentos mil réis) que lhe fora emprestado para a compra de sua alforria. A dívida seria paga em 30 meses, com trabalhos de marcenaria efetuados nas oficinas da Companhia União E Indústria. Jorge Carneiro iria receber $75 \$ 000$ (setenta e cinco mil réis) mensais, podendo retirar $25 \$ 000$

6 Segundo Sérgio de Oliveira Birchal, entre 1857 e 1859 o número total de trabalhadores livres e escravos empregados pela CUI saltou de cerca de 1.000 para 3.500 indivíduos. A partir de 1860, com o término das obras da Rodovia União E Indústria, no entanto, houve uma sensível diminuição do número de operários a serviço da Companhia:"em 1865, por exemplo, a companhia empregou um total de 344 pessoas, mas não há informação sobre o emprego de escravos e não-escravos” (BIRCHAL, 1998: 08-12).

7 Entre 1856 e 1861, a Companhia União E Indústria estabeleceu numa ampla área ao norte de Juiz de Fora - atuais bairros Morro da Glória, Mariano Procópio, Vale do Ipê, Democrata e Fábrica - a sua estação central, denominada Rio Novo, e suas principais oficinas e armazéns, uma grande olaria, além de um hotel e da escola mista da Colônia D. Pedro II, núcleo colonial cuja criação será objeto de análise específica no próximo item deste capítulo (PASSAGLIA, 1982: 29-31). 
(vinte e cinco mil réis) mensais para suas despesas e utilizando o restante para amortizar o débito (LACERDA, 2002: 72-74 e 111) ${ }^{8}$.

Nossa pesquisa mostrou que, a partir do final do ano de 1854 e ao longo do ano de 1855, Mariano Procópio iniciou a prática ilegal de alugar escravos para a obra em questão. Esse exercício é indicativo do bom uso das íntimas relações que o diretor da Companhia União \& Indústria possuía com D. Pedro II e contraria a ideia, atualmente generalizada, de que este era um Imperador consciencioso com relação à coisa pública ${ }^{9}$. Giroletti chegou a afirmar, pioneiramente, em sua obra clássica sobre a industrialização juizforana, que no trecho que liga Juiz de Fora a Paraíba do Sul cerca de 70\% dos 1136 trabalhadores eram escravos, totalizando, portanto, 795 escravos (GIROLETTI, 1987: 64).

Domingos Giroletti localizou duas empresas inglesas de mineração, a Cocais e a Gongo Soco, como locatárias de escravos para a Companhia União \& Indústria ${ }^{10}$. As citações foram extraídas do Álbum do Município de Juiz de Fora, de autoria de Albino Esteves, ou seja, uma obra pertencente à historiografia tradicional e que citou uma fonte oficial, a saber, um relatório de Presidente de Província (GIROLETTI, 1987: 63). Giroletti, contudo, não conseguiu encontrar a origem dos escravos locais alugados por Mariano Procópio, apesar de mencionar que este alugou escravos de outras fontes que não as duas empresas inglesas mencionadas.

8 Antonio Henrique Lacerda localizou ainda outras duas cartas de alforria compradas que se referiam a escravos pertencentes ou alugados à Companhia União E Indústria, sendo um empregado como carpinteiro e o outro no Hotel da Companhia. Este último chamava-se Custódio, tinha 22 anos em 1872, ano em que adquiriu sua liberdade por um conto de réis (LACERDA, 2002: 72-74 e 111).

9 José Murilo de Carvalho, em obra recentemente lançada sobre D. Pedro II cita parte das instruções à princesa Isabel, quando o Imperador aconselha "não indicar pessoas para cargos ou graças aos ministros exceto em circunstâncias muito especiais de maior proveito público". As relações entre o monarca e Mariano Procópio, assim como a ação do Estado imperial em relação à CUI, pareceram-nos bastante distintas dos conselhos dado à princesa. Cabe perguntar se o entendimento histórico acerca da forma de governo de D. Pedro II não se encontra excessivamente contagiada de anacronismo (ver CARVALHO, 2007: 89).

10 A Congo Seco,juntamente com outras empresas mineradoras inglesas, sofreu severas críticas da opinião pública brasileira, pois, enquanto a Inglaterra pressionava o Brasil no sentido de abolir a escravidão, essas empresas adotavam a mão de obra escrava em seus trabalhos. Para maiores detalhes sobre o tema, ver Costa (1997: 80). 
Contudo, ao analisarmos a documentação cartorária sob custódia do Arquivo Histórico do Município de Juiz de Fora, encontramos nos livros de compra e venda da Comarca de Barbacena dos anos de 1853 a 1855, no livro de escrituras públicas de compra e venda da Comarca do Paraibuna e no livro de escrituras públicas de compra e venda do cartório do Primeiro Ofício de Notas, ambos referentes aos anos de 1854 a 1856, a Companhia União \& Indústria alugando escravos para trabalhar na construção da dita rodovia. A utilização de escravos em obras públicas era vetada por lei ${ }^{11}$, porém esta foi claramente burlada por Mariano Procópio, contrariando dessa forma o consenso entre a historiografia local acerca da não utilização de escravos na construção da Rodovia União \& Indústria.

Apesar da grandeza dos números acima apresentados, a historiografia local continuou a aceitar o mito da mão de obra livre imigrante durante muito tempo ${ }^{12}$. A forte presença alemã, totalizando 1.193 pessoas, incluindo mulheres e crianças, continuou a ser apontada como a principal, se não a única responsável pela construção da rodovia ${ }^{13}$.

11 Segundo Luiz Felipe Alencastro, dois exemplos significativos de medidas oficiais restritivas ao emprego nas obras públicas na década de nos anos de 1860 são: "O 'Aviso' de 09/05/1862 que determina[va] a proibição do emprego de escravos nas obras da estrada de ferro Dom Pedro II [e] a circular de 10/01/1866 [que] odena[va] a demissão de todos os escravos empregados nas obras públicas executadas na província do Rio de Janeiro com os créditos do Ministério da Agricultura, Comércio e Obras Públicas". Ver ALENCASTRO, Luiz Felipe de. Proletários e escravos: imigrantes portugueses e cativos africanos no Rio de Janeiro, 1850-1872. Novos Estudos, São Paulo, Cebrap, n. 21, jul. 1988, pp. 42-43.

Desde a década de 1990, essa visão recebeu um duro golpe com as pesquisas realizadas por diferentes historiadores.Ver: GUIMARÃES, Elione Silva; GUIMARÃES,Valéria Alves. Aspectos Cotidianos da Escravidão em Juiz de Fora. Juiz de Fora: Funalfa, 2001. GUIMARÃES, Elione Silva. Violência entre parceiros de cativeiro: Juiz de Fora, segunda metade do século XIX. São Paulo: Fapeb, Annablume, 2006. LAMAS, Fernando Gaudereto; OLIVEIRA, Luís Eduardo. As vicissitudes da escravidão e da imigração em Minas Gerais: a Companhia União e Indústria, os escravos e os alemães (18521879). In: Encontro Escravidão e Liberdade no Brasil Meridional, 3. Anais... Florianópolis, 02-04 maio 2007. LACERDA, Antonio Henrique Duarte. Negócios de Minas: Família, fortuna, poder e redes de sociabilidades nas Minas Gerais - A Família Ferreira Armonde (1751-1850). Niterói: PPGH/UFF, Tese de Doutorado, 2010. OLIVEIRA, Luís Eduardo de. Os trabalhadores e a cidade: a formação do proletariado de Juiz de Fora e suas lutas por direitos (1877-1920). Juiz de Fora (MG): Funalfa; Rio de Janeiro: Editora da FGV, 2010.

13 Obviamente não queremos enveredar para o caminho diametralmente oposto, ou seja, o de negar a importância da participação da imigração alemã para a formação econômica de Juiz de Fora e, em especial, para a construção da Rodovia União \& Indústria. 
Queremos chamar a atenção para o importante papel exercido pela mão de obra escrava para a construção desta rodovia. Este ponto é de extrema importância, pois reafirma o caráter escravista/exportador da economia matense, particularmente da economia juizforana, uma vez que, como já foi anteriormente afirmado, esse era o principal aspecto de tal economia no período abordado.

Gostaríamos também de salientar o fato de que a historiografia nacional, por muito tempo, levou na mais alta conta a opinião dos estrangeiros que viajaram pelo Brasil, sem realizar uma crítica mais apurada do que essas pessoas falavam. Tal foi o que ocorreu com a utilização do trabalho escravo na construção da Rodovia União \& Indústria, já que os historiadores basearam-se exclusivamente na opinião de Agassiz acerca da utilização de escravos em obras públicas. Referendamos nossa opinião com as palavras de Domingos Giroletti a respeito do tema:

A ênfase na introdução dos imigrantes pela Companhia União \& Indústria como responsável pelo desencadeamento do processo de transformação das relações de produção não significa que as diversas frentes de trabalho para a abertura da Rodovia operassem exclusivamente com mão de obra livre (GIROLETTI, 1987: 63).

A princípio o engajamento deveria ser de apenas seis meses, podendo ou não ser renovado indefinidamente, sempre pelo mesmo prazo. Caso o locador optasse por romper o contrato, deveria avisar com 30 dias de antecedência ao prazo de reengajamento. O pagamento pelo aluguel realizava-se a cada três meses, e a Cia. União \& Indústria poderia, se lhe conviesse, sublocar o escravo para outras pessoas ${ }^{14}$.

Caso durante o contrato o escravo adoecesse, fugisse ou se ferisse a Companhia se responsabilizaria com os gastos. Se após 15 dias, o escravo doente não se recuperasse ou o escravo fugido não fosse encontrado, o locatário seria responsabilizado, ficando ao encargo deste o tratamento ou recuperação do escravo. Se a empresa de Mariano Procópio julgasse que o escravo alugado era inválido para o tipo de trabalho a ser exercido, avisaria ao locatário para tomar as

14 Arquivo Histórico da Cidade de Juiz de Fora. $1^{\circ}$ Oficio de Notas, Caixa 1, Livro 2. Fls. 08-09. 1855. 
devidas providências e substituir o referido escravo por outro mais apropriado $^{15}$.

É interessante notar que, nesse caso, as leis do Império brasileiro deram, em certa medida, continuidade às Ordenações Filipinas, uma vez que, segundo estas (Livro 4, Título 13), em caso de compra de escravos e/ou mulas "defeituosos" e se isso ocorresse sem que o vendedor esclarecesse ao comprador, este último teria o direito de trocar, ou de ter ressarcido o dinheiro gasto na compra ${ }^{16}$.

Cabe ainda destacar que a utilização de escravos em atividades que não se encaixavam diretamente na produção ou extração de produtos vendáveis no mercado externo, como foi o caso que analisamos até o momento, devia-se basicamente à estreiteza do mercado de trabalhadores livres (GORENDER, 1988: 484), tanto especializados quanto sem especialização. Além desse fato, deve ser ressaltado o aspecto racista, pois, como destacou Douglas Cole Libby, havia um grande preconceito em relação à mão de obra livre nacional, percebida como preguiçosa e inapta ao exercício regular do trabalho; em contrapartida, a mão de obra escrava era vista como perfeitamente adaptada ao trabalho, inclusive o industrial (LIBBY, 1984: 92).

Devemos ainda levar em conta que as províncias de Minas Gerais e Rio de Janeiro eram as que maior número de escravos concentravam na região Sudeste no último quartel do século XIX. Dados apresentados por Rômulo Andrade reforçam essa análise: segundo o autor, Juiz de Fora possuía, no ano de 1872, aproximadamente 19.141 escravos e, em 1883, esse número atingiu 21.808 cativos (ANDRADE, 2002: 3). Em outros termos, essa cidade presenciou um aumento considerável do número de escravos justamente nos últimos anos da escravatura brasileira, fato que reforçou a dependência da região em relação ao braço cativo, mesmo após o período de imigração europeia, principalmente, mas não exclusivamente, em relação à agricultura ${ }^{17}$.

15 Arquivo Histórico da Cidade de Juiz de Fora. $1^{\circ}$ Ofício de Notas, Caixa 1, Livro 2. Fls. 08-09. 1855.

16 Livro 4,Título 13: Dos escravos e mulas que mancam. In: Ordenações Filipinas. Edição organizada por Cândido Mendes de Almeida. Rio de Janeiro, 1870.

17 Para uma análise mais detalhada sobre a permanência, até as vésperas da abolição, da mão de obra escrava na agricultura em Juiz de Fora, ver Saraiva (2005: 47). 
Jacob Gorender, ao analisar a participação de escravos em atividades tipicamente fabris, incluiu-os no caso mais geral de escravidão urbana, e defendeu que "a escravidão urbana representou, em todas as formações escravistas, um complemento da escravidão rural" (GORENDER, 1988: 482). Essa observação é relevante para nosso estudo, uma vez que os escravos alugados por Mariano Procópio foram utilizados para a construção de uma rodovia que visava facilitar o escoamento da produção cafeeira da Zona da Mata Mineira para o porto do Rio de Janeiro. Em outros termos, visava eliminar um gargalo para uma economia exportadora de commodities.

Não obstante, a opinião de Jacob Gorender no que se refere à utilização de escravos em atividades especializadas referendou a ideia de muitos historiadores acerca da improdutividade e da irracionalidade do trabalho escravo ${ }^{18}$, uma vez que estes seriam usados apenas em trabalhos rústicos, que requeriam pouca ou nenhuma habilidade. Segundo Luis Carlos Soares:

Já a ideia de que os escravos eram ocupados somente em tarefas nãoespecializadas acaba reproduzindo alguns dos estereótipos utilizados por aqueles que, dentro dos princípios liberais, defendiam a colonização e o emprego maciço do trabalho livre na indústria, considerado de melhor qualidade que o trabalho cativo. Enquanto o trabalho livre, desenvolvido de preferência por homens brancos, era sinônimo de 'industriosidade', o trabalho escravo era associado exclusivamente à utilização da força fisica (SOARES, 2003: 02).

Mariano Procópio alugou uma quantidade considerável de escravos pertencentes a proprietários de Juiz de Fora, incluindo seus distritos e Barbacena. A tabela 1 abaixo indica o número de escravos alugados por Mariano Procópio ao longo dos anos de 1855 e 1856.

18 Muitos autores, ao longo da primeira metade do século XX, acreditaram que o uso do trabalho escravo, tanto da parte do próprio escravo quanto da parte de quem era proprietário e/ou locatário daquele, deveria ser qualificado como uma atividade irracional, uma vez que não se enquadrava dentro da lógica capitalista, supostamente racional, de assalariamento. Apesar de ser um debate pertinente, não entraremos em maiores detalhes neste artigo. Para maiores informações, ver Ianni (1998) e Cardoso (2003). Para uma crítica a essa visão, conferir Monastério (2005: 13-28). 
Tabela 1 - Número de escravos alugados pela Companhia União \& Indústria nos anos de 1855 e 1856

\begin{tabular}{c|c|c|c|c|c|c|c|c|c|c|c|c}
\hline $\begin{array}{c}\text { AnO/ } \\
\text { MÊS }\end{array}$ & Jan. & Fev. & Mar. & Abril & Maio & Jun. & Jul. & Ago. & Set. & Out. & Nov. & Dez. \\
\hline 1855 & 19 & 23 & --- & --- & 25 & --- & --- & 40 & --- & --- & --- & \\
\hline 1856 & & & & & & 10 & & & & & & 10 \\
\hline
\end{tabular}

Fonte: Arquivo Histórico da Cidade de Juiz de Fora. $1^{\circ}$ Ofício de Notas, Caixa 01, Livro 2. Fls. 08-09. 1855 e Caixa 1, Livro 3, fls. 01 e 02, 1856.

Nas escrituras de aluguel de escravos realizadas por Mariano Procópio encontramos escravos especializados em serviços como carpintaria e mesmo cozinheiras ${ }^{19}$, fato que corrobora a visão de Luis Carlos Soares e desmistifica a ideia de que os escravos eram utilizados apenas em serviços brutos. A pesquisa, nesse ponto, caminhou na mesma direção do artigo de Luis Carlos Soares, especialmente quando este afirmou, em relação à falta de técnica dos escravos, que:

(...) o emprego de escravos em oficinas artesanais e manufaturas pressupunha que eles tivessem que conhecer razoavelmente os segredos dos seus oficios manuais, principalmente naquelas primeiras, pois no processo artesanal cada trabalhador era responsável pela realização de todas as etapas necessárias à confecção de um determinado produto (SOARES, 2003: 02).

A quantidade de escravos alugados na região indica que a força de trabalho escrava exerceu um papel fundamental na construção da Rodovia União \& Indústria ao longo de todo o processo. Além do aspecto quantitativo, deve-se levar em conta também o tempo de engajamento dos escravos, já que três das dez escrituras alugavam seus escravos pelo tempo de dois anos, enquanto as outras três pelo tempo de quatro anos, duas pelo tempo de cinco anos. Tais dados permitem-nos concluir que o papel da mão de obra escrava foi muito relevante, uma vez que o período - mínimo de dois e máximo de cinco anos - cobre boa parte do período de construção da Rodovia, incluindo a fase em que os imigrantes alemães estiveram trabalhando.

Os valores pagos por Mariano Procópio também eram consideráveis. Em duas escrituras, uma realizada em 21 de janeiro de 1855 e outra realizada em 6 de maio do mesmo ano, Mariano Procópio desembolsou

19 AHCJF. $1^{\circ}$ Ofício de Notas. Caixa 1, Livro 2, fls. 8 e 30. 
17 contos e 352 mil Réis pelo tempo de quatro anos, um valor considerado alto para a época ${ }^{20}$.

O aluguel de 25 escravos pertencentes a Jorge Afonso de Golveias, residente na vila de Barbacena em maio de 1855, é esclarecido pelo Relatório do Presidente da Província de Minas Gerais, quando neste se afirmou o seguinte:"Dividem-se os trabalhos em duas categorias, compreendendo a primeira a reparação, e conservação da estrada atual desde a ponte do Parahybuna até a Cidade de Barbacena (...)"21 .As obras realizadas pela Companhia União \& Indústria incluíam, além da construção do trecho ligando Juiz de Fora a Petrópolis, a reforma do percurso Barbacena-Juiz de Fora. Daí a necessidade de alugar escravos de um proprietário que residisse próximo à localização das obras.

Mais adiante, no mesmo relatório, encontramos a seguinte constatação: "A reparação, e conservação da estrada actual do Parahybuna tem exigido constante emprego de não diminuto pessoal (...)" ${ }^{22}$. Como é notório, os imigrantes alemães chegaram a Juiz de Fora apenas no ano de 1858 (TRIBUNA DE MINAS, 2000: 02); logo, podemos concluir que o "não diminuto pessoal" referia-se à mão de obra escrava alugada aos proprietários locais por Mariano Procópio. Em outros termos, a utilização de escravos em uma obra pública foi não somente aceita como referendada pelas autoridades oficiais da Província, uma vez que, ainda no mesmo relatório, lê-se que “(...) os trabalhos desta companhia [União \& Indústria] foram executados no anno que decorreo do $1^{\circ}$ de fevereiro de 1855, e por mim examinados em grande parte quando vim da Corte para esta Capital [Ouro Preto]"23.

20 AHCJF. $1^{\circ}$ Ofício de Notas. Caixa 1, Livro 2, fls. 6-8 e 19-20.

21 Relatório que a Assembleia Legislativa Provincial de Minas Gerais apresentou na abertura da sessão ordinária de 1856. Conselheiro: Herculano Ferreira Penna, Presidente da Mesma Província. Ouro Preto. 1856. p. 12.

22 Relatório que a Assembleia Legislativa Provincial de Minas Gerais apresentou na abertura da sessão ordinária de 1856. Conselheiro: Herculano Ferreira Penna, Presidente da Mesma Província. Ouro Preto. 1856. p. 12.

23 Relatório que a Assembleia Legislativa Provincial de Minas Gerais apresentou na abertura da sessão ordinária de 1856. Conselheiro: Herculano Ferreira Penna, Presidente da Mesma Província. Ouro Preto. 1856. p. 12. 


\section{Mão de obra livre nos empreendimentos da CUI: germânicos, portugueses e brasileiros}

Mariano Procópio Ferreira Laje soube fazer bom uso das leis imperiais, especialmente daquelas referentes à contratação de estrangeiros. Segundo Osmani Teixeira de Abreu, o decreto que regulava o contrato para prestação de serviços executados por brasileiros e estrangeiros foi aprovado pela Assembleia Geral em 13 de setembro de 1830 e suas disposições vigoraram até 15 de março de 1879, “quando foram revogadas pelo Decreto n. 2.827" (ABREU, 2005: 23). Mariano Procópio utilizouse também de uma prática muito comum nesse período, a saber, a criação de uma sociedade de colonização. Segundo Teresa Schorer Petrone, tais sociedades eram "muitas vezes subsidiadas pelos governos", e sua finalidade era "promover por todos os meios o aumento da imigração, patrocinar as reformas legislativas, visando ao bem-estar do imigrante, e fazer propaganda na Europa no sentido de destruir ideias falsas sobre o Brasil" (PETRONE, 1985: 280).

Sérgio de Oliveira Birchal indicou que, dos 1.102 homens de que dispunha a CUI em 1856, 18\% ou 202 indivíduos eram artífices e jornaleiros livres, em sua maioria brasileiros, alguns qualificados e possivelmente recrutados nos arrabaldes dessa cidade, onde a empresa instalou suas principais oficinas e a sede de sua administração ${ }^{24}$. Desse contingente de operários não-escravos, fazia parte ainda um grupo de aproximadamente vinte oficiais de oficio germânicos, contratados em Hamburgo no segundo semestre de 1855 e que chegaram a Juiz de Fora, com suas respectivas famílias, em janeiro do ano seguinte ${ }^{25}$. Tratava-se, como

24 No corpo técnico e administrativo da Companhia União E Indústria - composto de engenheiros, arquitetos, agrimensores, gerentes e seus assistentes - era marcante a presença de estrangeiros, sobretudo de origem francesa e germânica. Mas, como assinala Sérgio de Oliveira Birchal, alguns brasileiros e até mesmo portugueses chegaram a integrar postos-chave na estrutura hierárquica da CUI. O relatório de 1857 dessa empresa, por exemplo, informou a seus acionistas "que um engenheiro brasileiro (...) foi contratado para assumir o lugar de um dos engenheiros franceses cujo contrato havia expirado". De acordo ainda com o autor, dos 30 nomes listados como formando o staff da Companhia em 1865, "22 eram sem sombra de dúvida nomes de origem portuguesa, que é uma forte evidência do emprego de brasileiros" (BIRCHAL, 1998: 10-12).

25 O Relatório da Assembléia Geral dos Acionistas da Companhia União e Indústria, relativo ao ano de 1856, segundo Sérgio de Oliveira Birchal, confirma que o número de 
explicam Luiz José Stheling e Domingos Giroletti, de artífices experientes e de ramos manufatureiros variados - mecânicos, fundidores, ferreiros, folheiros, ferradores, segeiros, seleiros, carpinteiros, marceneiros, pontoneiros, pedreiros, pintores e oleiros - que dispunham de um contrato com a Companhia União \& Indústria que, em resumo, lhes garantia trabalho durante dois anos, com salários médios de $2 \$ 000$ por dia, pagos ao final de cada mês, além de transporte, moradia e alimentação durante todo esse período ${ }^{26}$.

Cerca de dois anos depois, entre janeiro e agosto de 1858, novas levas de imigrantes germânicos foram trazidas a Juiz de Fora, dessa vez não apenas para trabalharem nas oficinas, estações e estradas que a Companhia União \& Indústria construía na região, como também para povoarem a colônia agrícola $D$. Pedro II, organizada com vultosos recursos obtidos por essa empresa junto ao governo imperial. É possível que além dos fortes vínculos que o presidente da CUI, Mariano Procópio Ferreira Lage, mantinha com o monarca brasileiro, a existência de uma cláusula que vedava (mas que não impediu de fato) o emprego de cativos nas obras contratadas com o Estado tenha contribuído para que a direção daquela companhia conseguisse a rápida liberação de uma considerável soma de dinheiro público para a importação desses colonos ale-

operários especializados alemães contratados inicialmente pela empresa não excedia duas dezenas. Tais artífices, juntamente com seus familiares, partiram de Hamburgo com destino ao Brasil, a bordo do veleiro Antílope, no dia 2 de novembro de 1855. Desembarcaram no Rio de Janeiro em 28 de dezembro, seguindo em carroções para Juiz de Fora, onde teriam sido recebidos com "grande festa" uma semana depois. Desse grupo fazia parte, possivelmente, o chefe da ferraria das oficinas da CUI, Balthazar Espeschit (?-1890), originário do Grão-Ducado de Essen, no vale do Rur, onde trabalhou para a família Krupp (BIRCHAL, 1998: 11 \& ESPESCHIT, 1995: 149-150).

26 Eram esses, pelo menos, os benefícios garantidos no "contrato-padrão" firmado, em 11 de outubro de 1855, entre o preposto da CUI em Hamburgo, H. F. Eschels, e o mestre de seges Heinrich Julios Griese (1826-1917), natural de Preetz, Holstein. Por esse contrato, cabia ao artífice "servir a Companhia União e Indústria (...) fazendo toda a obra de seu oficio e segundo for, caixas de seges, carruagens e carros de correio, assim como toda a obra de carro de correio e de carreto" pelo prazo de dois anos, contados a partir de janeiro de 1856, quando chegou a Juiz de Fora. Além desse segeiro, Luiz José Stheling identificou apenas outros cinco artífices germânicos que se estabeleceram dessa forma na cidade: os ferreiros Pedro Schubert Sênior e João Ulrico Schiess, os seleiros João Stiegert e Baltazar Weydt, e o folheiro Frederico Peters (STEHLING, 1979: 149-152, 415, 429-432). 
mãe ${ }^{27}$. Tais trabalhadores provinham, em sua maioria, do grão-ducado de Hessen, do Tirol, da Prússia, de Holstein e Baden, e pertenciam a distintos segmentos profissionais (agricultores, sapateiros, alfaiates, barbeiros, carpinteiros, pedreiros, parteiras, padeiros, carroceiros, relojoeiros, marceneiros, ferreiros, funileiros, pintores, ferreiros, carpinteiros de carros, serralheiros, entre outros ${ }^{28}$.

$\mathrm{Na}$ verdade, esses imigrantes se fixaram no município sob condições bastante diversas daquelas oferecidas, pelo menos em termos contratuais, aos artífices germânicos que desde janeiro de 1856 viviam e trabalhavam em Juiz de Fora. Primeiramente porque os colonos chegados em 1858, além de serem obrigados a reembolsar as despesas com as viagens marítima e terrestre e pagar por outras "antecipações" eventualmente recebidas (moradia, víveres, ferramentas, pequenos animais de criação), deviam saldar também o valor dos seus respectivos prazos na Colônia D. Pedro II. Por outro lado, quando se empregavam como operários nas oficinas e canteiros de obra da CUI, tinham que se submeter a ordenados bem menores, de $1 \$ 000$ em média ${ }^{29}$.

27 Para Luiz José Stheling, mais do que garantir a mão de obra qualificada e barata que os seus empreendimentos exigiam, a entrada da CUI no ramo de imigração e colonização visou, fundamentalmente, "o dinheiro existente nos cofres da Repartição Geral de Terras Públicas", no caso, 200 contos de réis antecipados para importação e assentamento de dois mil alemães - ainda que apenas 1.162 tenham sido trazidos e fixados, de fato, na Colônia D. Pedro II. Tais recursos, além de auxiliarem na capitalização da Companhia, permitiram que seus dirigentes adquirissem e subdividissem uma vasta área inculta ao norte da cidade, obtendo lucros consideráveis, ao que parece, com a venda a prestações de cerca de 188 lotes de terras ou "prazos" aos colonos (STEHLING, 1979: 153-160).

28 No capítulo sétimo de seu livro Juiz de Fora, a Companhia União e Indústria e os alemães, Luiz José Stheling reuniu um conjunto bastante relevante de informações sobre a constituição e o desenvolvimento inicial da Colônia D. Pedro II, tais como: as transcrições do acordo firmado entre a CUI e a Repartição Geral de Terras Públicas, que financiou a implantação desse núcleo colonial em Juiz de Fora, e do contratopadrão que os imigrantes alemães assinaram antes de embarcarem para o Brasil; a relação de sobrenomes dos colonos e o mapa com a localização precisa de seus respectivos prazos na Colônia; trechos de relatórios oficiais e consulares referentes às condições gerais de existência desses imigrantes no início da década de 1860, dentre outros documentos (STEHLING, 1979: 149-207).

29 Por volta de 1860, a Colônia D. Pedro II dividia-se em três regiões: a Villagem (hoje rua Bernardo Mascarenhas e bairro Fábrica), onde residia a maior parte dos colonos empregados na CUI; a "colônia de baixo" (atual bairro Borboleta) e a "colônia de cima” (região hoje conhecida como São Pedro e Cidade Alta), essencialmente agrí- 
Em dezembro de 1860, segundo cálculos de Domingos Giroletti, a Companhia União \& Indústria empregava em suas obras, estações e oficinas aproximadamente $70 \%$ da população masculina da Colônia D. Pedro II apta ao trabalho. Dos salários recebidos por esses operários, cerca de um quarto era destinado compulsoriamente à amortização de suas respectivas dívidas com tal firma. Esse endividamento, como notou o autor, mantinha grande parte dos colonos atada aos ditames da empresa: "De um montante de 73,8 contos em 1867, a dívida foi reduzida para 67,3 contos em 1870, ou seja, (...) não havendo acréscimo de juros por mora, seriam necessários mais de trinta anos para integralizá-la”, se mantida a média de sua redução anual em 2,1 contos de réis ${ }^{30}$.

Por contrastar em tudo com o que havia sido anteriormente prometido pelos representantes da Companhia União \& Indústria em Hamburgo, essa realidade degradante - que se tornava mais grave com os constantes atrasos de salários, as péssimas condições de habitação e a escassez de gêneros alimentícios - constituiu a principal causa de uma tentativa de sublevação na Colônia D. Pedro II em fins de 1858. Apesar de essa ameaça de levante ter sido prontamente reprimida pelo destacamento policial local, que encarcerou por alguns dias os seus supostos líderes, o clima de tensão não diminuiu, motivando inclusive o protesto formal do representante diplomático do Reino da Prússia no Brasil, barão de Meusebach, contra "os maus tratos e as explorações que constatara pessoalmente nas visitas" que realizou, nessa época, à citada colô-

colas. Em dezembro daquele ano, esse núcleo colonial abrigava 1.144 pessoas, 54,4\% do sexo masculino e cerca de 45\% de credo luterano (STEHLING, 1979: 188-191; PASSAGLIA, 1982: 29-31).

Cabe ressaltar, nessa perspectiva, que a difícil situação imposta aos habitantes da Colônia D. Pedro II era bastante semelhante ao endividamento e aos problemas enfrentados pelos cerca de 900 alemães assentados, entre 1840 e 1850, na fazenda Ibicaba, em Limeira - SP. Embora trazidos ao Brasil com recursos públicos, esses imigrantes estavam submetidos a um "sistema de parceria" que os obrigava tanto a entregar ao latifundiário e senador Nicolau de Campos Vergueiro metade da renda obtida com o cultivo de cafezais e de outros produtos agrícolas, quanto a saldar os adiantamentos feitos (transporte marítimo e terrestre, ferramentas, gêneros alimentícios e habitação). Indignados e exigindo "tratamento justo", em dezembro de 1856, os colonos se revoltaram e se recusaram a pagar suas dívidas, que se avolumavam a cada ano, em virtude da incidência de juros e da manipulação de seus valores pela empresa do citado cafeicultor, a Vergueiro E Companhia (GIROLETTI, 1987: 56-62; FERRÃO, 1999: 03-06). 
nia agrícola. Segundo Luiz José Stheling, aconselhados pelo diplomata prussiano, desde então muitos colonos se recusaram a pagar a dívida que lhe era atribuída pela empresa, enquanto alguns preferiram ainda se mudar para outras áreas, na cidade ou fora dela ${ }^{31}$.

Embora sejam ainda bastante restritos e fragmentados os dados disponíveis sobre os trabalhadores lusos e brasileiros empregados pela CUI, de meados dos anos 1850 até fins da década de 1870, há fortes razões para se acreditar que esses operários recebiam os mesmos salários baixos e aviltantes pagos, então, aos colonos germânicos ${ }^{32}$. Soma-se a essas precárias condições de existência, dando a elas um aspecto ainda mais grave, o fato de que nas cidades e fazendas das províncias cafeeiras, em especial, grande parte dos imigrantes portugueses e alemães, a exemplo do que ocorria com muitos jornaleiros nacionais livres, eram obrigados a labutar, ombro a ombro, com cativos de todos os tipos ${ }^{33}$.

Em cartas enviadas à Alemanha, entre as décadas de 1850 e 1860, o colono João Ziegler informou a seus parentes, dentre outras coisas, que

31 A notícia veiculada na Europa, ao longo da década de 1850, de que muitos dos que emigraram para as províncias cafeeiras brasileiras encontravam-se em uma situação análoga à dos escravos, alarmou a opinião pública de vários países, sobretudo após a revolta na fazenda de Ibicaba, em 1856. Devido aos problemas e protestos suscitados pelos famigerados "contratos de parceria", por exemplo, as autoridades da Suíça e de Portugal passaram a desaconselhar a emigração para o Brasil, enquanto o governo da Prússia, a partir de novembro de 1859, proibiu a preparação de viagens com esse fim e destino (STEHLING, 1998: 206-207; CARNEIRO, 2004: 183-208; FERRÃO, 1999: 6).

32 Entre os artífices e trabalhadores braçais estrangeiros engajados pela Companhia União E Indústria, de 1855 a 1861, predominavam os germânicos e lusitanos. Mas, segundo Sérgio de Oliveira Birchal, os brasileiros livres da região eram também uma importante fonte de mão de obra qualificada e não qualificada: "Em 1856, por exemplo, a companhia empregou um total de 80 brasileiros não-escravos no empedramento da estrada. O relatório de 1857 (...) afirmava que o número de brasileiros recrutados tinha aumentado e que as oficinas estabelecidas em Juiz de Fora empregavam tanto alemães quanto brasileiros" (BIRCHAL, 1998: 10-12).

33 A citada passagem do barão de Meusebach por Juiz de Fora, em dezembro de 1860, ilustra bem essa situação. Ao que parece, antes de inspecionar a Colônia D. Pedro II, o representante diplomático do reino da Prússia junto ao governo brasileiro havia percorrido diversas fazendas localizadas na divisa das províncias do Rio de Janeiro e Minas Gerais. Nessas visitas, de acordo com Luiz José Stheling, o diplomata prussiano "pôde constatar que, de fato, procediam as reclamações dos colonos alemães de que estavam recebendo o mesmo tratamento dos escravos negros" (STEHLING, 1979: 206-207). 
trabalhavam então cerca de dez horas por dia em uma pedreira da CUI. Embora se mostrasse otimista em relação à exploração de seu prazo na Colônia D. Pedro II, relatava que metade de seu ordenado era retida mensalmente pela empresa, a título de amortização de dívidas. Numa carta de abril de 1862, em particular, admitiu estar passando por grandes dificuldades:

Pois estamos agora construindo uma nova casa e há oito meses a Companhia não faz pagamento porque ela está ruim. (...) Já há muito tempo porém estávamos esperando o pagamento e como ouvimos falar este poderá demorar ainda três meses (STEHLING, 1979: 306-310).

Esse cotidiano de exploração e miséria, permeado pelas brutalidades do sistema escravista, não estava muito distante da realidade enfrentada, na maior parte do terceiro quartel dos oitocentos, pelos operários germânicos, portugueses e brasileiros nos empreendimentos e domínios da Companhia União \& Indústria. Cabe lembrar, nesse sentido, que durante a construção da rodovia que ligava Juiz de Fora a Petrópolis, e também de seus vários ramais, os artífices não-escravos configuraram-se enquanto maioria apenas em certos serviços especializados, como a edificação de pontes e a operação das estações de muda e carga distribuídas ao longo dessas estradas. No regime de trabalho em que esses indivíduos juridicamente livres encontravam-se inseridos, por conseguinte, muitas práticas características do mundo senhorial se faziam presentes, como evidenciam as jornadas de mais de dez horas diárias que tinham que cumprir, os salários baixíssimos que recebiam - geralmente com atrasos de até onze meses e com descontos que chegavam à metade do seu valor nominal - e a repressão e punição daqueles que ousassem se contrapor a esse quadro de injustiças.

\section{Contexto após 1865: uso mais intenso de mão de obra livre}

No que se refere especificamente à composição da força de trabalho, entretanto, nos anos posteriores à inauguração da referida malha viária, a situação parece ter se invertido por completo, sobretudo em função 
da demanda cada vez maior dos cafeicultores da região por cativos. Com efeito, ao percorrer pela primeira vez a ligação macadamizada entre Petrópolis e Juiz de Fora, acompanhando seu marido e outros membros da expedição científica liderada por ele, a escritora norte-americana Elizabeth Cary Agassiz notou que desde 1865, pelo menos, a direção da CUI procurava se adequar à política imperial de restringir o uso de mancípios em obras e serviços públicos:

Para a conservação das estradas, (...) para as reparações, por exemplo, que exigem grande quantidade de trabalhadores constantemente em ação, explorando as pedreiras, quebrando pedras para o macadame, cobrindo o sulco deixado pelas rodas, retificando os taludes, etc., só se admitem trabalhadores livres (principalmente alemães e portugueses). Esse cuidado em excluir os escravos dos trabalhos públicos (...) inspira-se na ideia de limitar pouco a pouco o trabalho servil às ocupações agrícolas, afastando os escravos das grandes cidades e suas vizinhanças ${ }^{34}$.

A presença massiva e diligente desses homens se fazia indispensável, sobretudo, após períodos de chuvas intensas e entre os meses de maio e outubro, quando se processava o escoamento do grosso da produção cafeeira da Zona da Mata mineira para o seu principal porto exportador. De fato, a julgar pelo volume total de mercadorias transportadas por essa via durante os seus dez anos iniciais de operação, detalhado na Tabela 2, até meados da década de 1870, a CUI necessitou manter numerosas turmas de operários ao longo da extensa malha viária sob sua concessão - malha esta que, se somadas as extensões da estrada-tronco e dos seus quatro ramais nas províncias de Minas Gerais e do Rio de Janeiro, totalizava cerca de 408 quilômetros em 1868.

34 A primeira viagem do naturalista Louis Agassiz (1807-1873) pela Rodovia União E Indústria, ocorreu em maio de 1865 e tinha como destino a cidade de Juiz de Fora, onde os membros de sua expedição científica recolheram diversas espécies de peixes e outros pequenos animais com o concurso de inúmeros moradores locais, inclusive de "vários alemães empregados na estrada". Cumpre esclarecer que o texto do livro Viagem ao Brasil, publicado originalmente em 1868, foi quase todo elaborado por Elizabeth Cary Agassiz, que se encarregou de narrar as cenas pitorescas e descrever as paisagens, cabendo a seu marido acrescentar notas explicativas, um capítulo final e um apêndice à obra (AGASSIZ e AGASSIZ, 2000: 80-83, 93-96). 
Tabela 2 - volume total de café e de mercadorias transportadas pela companhia união \& indústria -1858 / 1868 (em toneladas)

\begin{tabular}{c|c|c|c}
\hline Anos & $\begin{array}{c}\text { Total de café } \\
\text { transportado }(\mathrm{A})\end{array}$ & $\begin{array}{c}\text { Total de mercadorias } \\
\text { transportadas (B) }\end{array}$ & $\%$ A / B \\
\hline 1858 & 7.400 & 10.974 & $67 \%$ \\
\hline 1859 & 15.908 & 22.776 & $70 \%$ \\
\hline 1860 & 20.024 & 26.970 & $74 \%$ \\
\hline 1861 & 23.179 & 29.743 & $78 \%$ \\
\hline 1862 & 11.342 & 20.695 & $55 \%$ \\
\hline 1863 & 14.495 & 23.345 & $62 \%$ \\
\hline 1864 & 13.042 & 23.802 & $55 \%$ \\
\hline 1865 & 19.242 & 31.998 & $60 \%$ \\
\hline 1866 & 19.504 & 32.627 & $60 \%$ \\
\hline 1867 & 29.139 & 41.061 & $71 \%$ \\
\hline 1868 & 24.602 & 36.641 & $67 \%$ \\
\hline Total & 197.877 & 300.632 & $66 \%$ \\
\hline
\end{tabular}

Fonte: (PIRES, 1993: 56).

Desse modo, entre as décadas de 1850 e 1870, tanto os cativos quanto os indivíduos livres pobres desempenharam, em maior ou menor grau, papéis fundamentais nesse processo de consolidação e expansão da produção cafeeira na região. Como sugere o conjunto de informações apresentado até aqui, após ter sido amplamente empregado nas obras de implantação da rede de estradas da CUI, o braço servil foi fortemente confinado na lavoura, cabendo quase que exclusivamente a assalariados germânicos, portugueses e brasileiros a realização dos serviços rotineiros de manutenção da referida malha viária.

Ao que tudo indica, esses trabalhadores livres foram majoritários também na operação das grandes oficinas, da olaria e da telheira que a Companhia União \& Indústria mantinha nos arredores de Juiz de Fora. Era justamente nesse complexo manufator, seguramente o mais importante da região até o início da década de 1870, que a CUI produzia boa parte do material empregado na edificação e manutenção de suas estações, além das carroças e diligências que trafegavam pela malha rodoviária sob sua administração (STEHLING, 1979: 144-145; GIROLETTI, 1987: 63-65; BIRCHAL, 1998: 10-12).

Durante toda a década de 1860, o trabalho e a produção permaneceram intensos nessas oficinas, tendo em vista o crescimento contínuo verificado no volume de cargas e passageiros transportados pela CUI 
na sua principal estrada e em seus diversos ramais na região, que requeriam e recebiam manutenção constante, como indicado nos parágrafos anteriores $^{35}$. Tal complexo manufator só arrefeceu o ritmo de sua movimentação em meados do decênio seguinte, como consequência direta da gradativa diminuição do fluxo geral pela Rodovia União \& Indústria, que perdia a sua importância relativa à medida que novos trechos da ferrovia D. Pedro II eram franqueados ao tráfego - situação que contribuiu decisivamente para a própria falência daquela companhia, ocorrida por volta de 1879. Com efeito, vinte e poucos anos após terem sido percorridas pelo imperador e por destacados membros das elites locais, aquelas antigas instalações manufatureiras foram alienadas para um consórcio integrado por industriais e negociantes radicados no Rio de Janeiro. Nessa mesma época, houve a extinção oficial da Colônia D. Pedro $I I^{36}$.

\section{Referências bibliográficas}

ABREU, Osmani Teixeira de. As relações de trabalho no Brasil desde 1824. São Paulo: LTr, 2005.

ANDRADE, Rômulo. Apontamentos sobre a microeconomia do escravo e sua interação com a família e as solidariedades (Zona da Mata de Minas Gerais, século XIX). In: Seminário sobre a Economia Mineira, 10. Anais... Belo Horizonte:UFMG;Diamantina:Cedeplar, 2002. Disponível em http://www.cedeplar.ufmg.br/diamantina2002/ textos/D09.PDF

35 Dados compilados por Albino Esteves demonstram que o volume de cargas transportado anualmente pela Rodovia União \& Indústria passou de 746.407 arrobas em 1858, para 3.591.527 arrobas em 1869 - valores ainda maiores, portanto, do que os expressos na Tabela 7 (1956:57). No mesmo período, o movimento anual de passageiros por essa estrada saltou de 5.499 para 23.975 pessoas (ESTEVES, 1956: 244-264).

36 No início de 1879, o contrato que a Companhia União \& Indústria mantinha com o governo imperial para os serviços de conservação e transporte pela rodovia entre Juiz de Fora e Petrópolis expirou e não foi renovado pelos administradores da empresa, que por essa época encerrou definitivamente as suas atividades e teve seu patrimônio e negócios entregues a uma Comissão Liquidante. Esta, por seu turno, após vender em julho de 1883 os terrenos e as instalações das antigas oficinas da CUI para a Companhia de Fiação e Tecelagem Industrial Mineira, coordenou o processo de extinção da Colônia D. Pedro II, concluído em meados de 1885. (BASTOS, 1991:4245 \& STEHLING, 1979: 240-243 e 311-313). 
AGASSIZ, Luís; AGASSIZ, Elizabeth Cary. Viagem ao Brasil (1865-1866). Brasília: Senado Federal, 2000.

ALENCASTRO, Luiz Felipe de. Proletários e escravos: imigrantes portugueses e cativos africanos no Rio de Janeiro, 1850-1872. Novos Estudos, São Paulo, Cebrap, 21, jul. 1988.

ALMEIDA, Maurício Luiz Campelo Bertola de. O preço de um fracasso: a companhia União e Indústria, a política e a economia no império (1852-1872). Dissertação de Mestrado. São Paulo: FFLCH / USP, 2002.

BARBOSA, Waldemar de Almeida. História de Minas Vol. 2. Belo Horizonte: Comunicação. 1979

BASTOS, Wilson de Lima. Mariano Procópio Ferreira Lage: sua vida, sua obra, sua descendência, genealogia. Juiz de Fora: Edições Paraibuna, 1991.

BIRCHAL, Sérgio de Oliveira. O mercado de trabalho mineiro no século XIX. História Econômica \& História da Empresa, n. ${ }^{\circ}$ 01, São Paulo, Hucitec, 1998, pp. 10-11.

BLASENHEIN, Peter. As ferrovias de Minas Gerais no século dezenove. Locus: revista de história. Juiz de Fora: NHR / EDUFJF, 1996, vol. 2, n. ${ }^{\circ}$ 2, pp. 81-110.

CARDOSO, Fernando Henrique. Capitalismo e escravidão no Brasil meridional: o negro na sociedade escravocrata do Rio Grande do Sul. $5^{\circ}$ ed. Rio de Janeiro: Civilização Brasileira. 2003.

CARNEIRO, Deivy Ferreira. Conflitos, crimes e resistência: uma análise dos alemães e teuto-descendentes através de processos criminais (Juiz de Fora - 1858/1921). Rio de Janeiro: UFRJ, 2004.

CARVAlHO, José Murilo de. D. Pedro II. São Paulo: Companhia das Letras, 2007.

ESPESCHIT, Lindolpho. Pelos caminhos do Brasil o que encontrei: histórias que me contaram, histórias que pesquisei, histórias que vivi. Belo Horizonte, Mazza, 1995.

ESTEVES, Albino. Mariano Procópio: trabalhos originais. Revista do Instituto Histórico e Geográfico Brasileiro. Rio de Janeiro; jan / mar. 1956, pp. 244-264.

FERRÃO, André Munhoz de Argollo. Colonos na fazenda Ibicaba, empresários em Piracicaba: a evolução sócio-econômica de um grupo de imigrantes alemães (18501880). III Congresso Brasileiro de História Econômica e IV Conferência Internacional de História de Empresas. Curitiba, UFPR / ABPHE, 1999.

GIROLETTI, Domingos. Industrialização de Juiz de Fora (1850-1930). Juiz de Fora: EDUFJF, 1987.

GITAHI, Maria Lúcia Caira. Os trabalhadores da construção civil 1889-1914. In: Anais do II Congresso Brasileiro de História Econômica e $3^{\circ}$ Conferência Internacional de História de Empresas. Vol.V. Niterói. 13 a 16 de outubro de 1996.

GORENDER, Jacob. O escravismo colonial. $5^{\circ}$ ed. São Paulo: Ática. 1988.

HARDMAN, Francisco Foot; LEONARDI,Victor. História da indústria e do trabalho no Brasil: das origens aos anos vinte. São Paulo: Ática, 1991.

IANNI, Octavio. As metamorfoses do escravo. $2^{\circ}$ ed. São Paulo: Hucitec. 1998.

JUIZ DE FORA - 150 anos. Imigrantes. Edição comemorativa dos 150 anos de Juiz de Fora. 31 de maio de 2000. Tribuna de Minas. 
LACERDA, Antonio Henrique Duarte. Os padrões das alforrias em Juiz de Fora, um município cafeeiro em expansão (Zona da Mata de Minas Gerais,1844-88). Dissertação de Mestrado. Niterói: UFF, 2002.

LIBBY, Douglas Cole. Trabalho escravo e capital estrangeiro no Brasil: o caso de Morro Velho. Belo Horizonte: Itatiaia, 1984.

MELO, Hildete Pereira de. Ferrovias e café: Rio de Janeiro e Minas Gerais 1850/1910. In LIBBY, Douglas Coly e PAIVA, Clotilde Andrade (org.). 20 anos do seminário sobre a economia mineira: história econômica e demografia histórica. Belo Horizonte, Cedeplar, v. 2, 2002.

MONASTÉRIO, Leonardo. FHC errou? A economia da escravidão no Brasil meridional. História e Economia. Brazilian Business School.Vol. 1, nº 1, São Paulo: Terra Comunicação Editorial, 2005, pp.13-28.

OBERACKER JÚNIOR, Carlos H. A contribuição teuta à formação da nação brasileira Vol. 2. $2^{\circ}$ ed. Rio de Janeiro: Presença. 1985.

PETRONE, Teresa Schorer. Imigração assalariada. In: HOLANDA, Sérgio Buarque de. O Brasil monárquico Vol. II: reações e transições. 5 ed. São Paulo: DIFEL, 1985.

PASSAGLIA, Luiz Alberto do Prado. A preservação do patrimônio histórico de Juiz de Fora-medidas iniciais. Juiz de Fora: PJF / IPLAN, 1982.

PAUlA, Maria Carlota. As Vicissitudes da Industrialização Periférica: o caso de Juiz de Fora (1930-1970). Dissertação de Mestrado. Belo Horizonte: UFMG, 1976.

PIRES, Anderson José. Capital Agrário, Investimento e crise na cafeicultura de Juiz de Fora (1870-1930). Dissertação de Mestrado. Niterói: UFF, 1993.

SARAIVA, Luiz Fernando. Estrutura de Terras e transição do trabalho em um grande centro cafeeiro, Juiz de Fora, 1870-1900. Revista Científica da FAMINAS-Vol. 1, Nº 2, Muriaé, FAMINAS, 2005, pp. 185-189.

. Um correr de casas, antigas senzalas: a transição do trabalho escravo ao trabalho livre em Juiz de Fora. Dissertação de Mestrado. Niterói: UFF, 2001.

STEHLING, Luiz José. Juiz de Fora, a Companhia União e Indústria e os alemães. Juiz de Fora: FUNALFA, 1979.

SEVCENKO, Nicolau. Introdução: prelúdio republicano, astúcias da ordem e ilusões do progresso. In: SEVCENKO, Nicolau (Org.) História da vida privada no Brasil Vol. 3 (República: da Belle Époque à era do rádio). São Paulo: Companhia das Letras, 1998.

SOARES, Luis Carlos. Escravidão industrial no Rio de Janeiro do século XIX. V Congresso Brasileiro de História Econômica e $6^{\circ}$ Conferência Internacional de História de Empresas. ABPHE: Caxambu. 7 a 10 de setembro de 2003. 